2014

\title{
Charter Values and Administrative Justice
}

Lorne Sossin

Osgoode Hall Law School of York University, lsossin@osgoode.yorku.ca

Mark Friedman

Follow this and additional works at: http:// digitalcommons.osgoode.yorku.ca/olsrps

\section{Recommended Citation}

Sossin, Lorne and Friedman, Mark, "Charter Values and Administrative Justice" (2014). Osgoode Legal Studies Research Paper Series. 62. http://digitalcommons.osgoode.yorku.ca/olsrps/62 


\section{OSGOODE}

OSGOODE HALL LAW SCHOOL

YOR K U N I VERSITY

\section{OSGOODE HALL LAW SCHOOL}

LEGAL STUDIES RESEARCH PAPER SERIES

Research Paper No. 13/2014

Vol. 10, No. 5 (2014)

Charter Values and Administrative Justice

Working Paper

Lorne Sossin

Mark Friedman

\section{Editors:}

Peer Zumbansen (Osgoode Hall Law School, Toronto; Canada Research Chair in Transnational Economic Governance and Legal Theory - Editor in Chief)

Stephen Ji (Osgoode Hall Law School, Toronto - Production Editor) 
Osgoode Legal Studies Research Paper No. 13/2014

Vol. 10, No. 5(2014)

\title{
Charter Values and Administrative Justice
}

Working Paper

Lorne Sossin and Mark Friedman

\begin{abstract}
:
What would the Charter of Rights and Freedoms have looked like if it had been designed for administrative justice? This is a question underlying this study. Ever since the Canadian Supreme Court made clear in Slaight Communications that discretionary decisions of public officials were to be subject to the Charter of Rights and Freedoms, and expanded the reach of the Charter to most adjudicative tribunals, the Court has wrestled with the coherence of the relationship between the Charter and administrative justice. The Court attempted to synthesize its position and chart a new path forward beyond a traditional application of the Charter to incorporate a potentially broader but inchoate set of "Charter values" in its 2012 decision Doré. With this decision as a point of departure, the author's elaborate a new framework for the development and application of Charter values in the distinct sphere of administrative justice.
\end{abstract}

\section{Keywords:}

Charter of Rights and Freedoms, Charter values, administrative justice, administrative law, constitutional law, public law, Slaight Communications, Doré

\section{Author(s):}

Lorne Sossin

Dean \& Professor

Osgoode Hall Law School

York University, Toronto

E: Isossin@osgoode.yorku.ca

Mark Friedman

JD Candidate, Class of 2015

Osgoode Hall Law School

York University, Toronto

E: markfriedman@osgoode.yorku.ca 


\section{Charter Values and Administrative Justice - Lorne Sossin ${ }^{1}$ and Mark Friedman ${ }^{2}-$ Draft November 10, 2013}

\section{A. Introduction}

What would the Charter of Rights and Freedoms have looked like if it had been designed for administrative justice? This is a question underlying our analysis in this study. Ever since the Supreme Court made clear in Slaight Communications that discretionary decisions of public officials were to be subject to the Charter, ${ }^{3}$ and expanded the reach of the Charter to most adjudicative tribunals, ${ }^{4}$ the Court has wrestled with the coherence of the relationship between the Charter and administrative justice. The Court attempted to synthesize its position and chart a new path forward beyond a traditional application of the Charter to incorporate a potentially broader but inchoate set of "Charter values" in its 2012 decision Doré. ${ }^{5}$ With this decision as a point of departure, we elaborate below on the scope of Charter values and their distinct implication for administrative justice.

Administrative justice is defined by its diversity. While courts in every part of the country look roughly similar (all have a dais for the judge, a jury box, a chair for witnesses, counsel tables, a gallery for spectators, etc), few people can close their eyes and picture what a landlord tenant board, immigration and refugee board, or social benefits tribunal look like. Yet that is where a vulnerable tenant goes to stave off eviction, where a refugee claimant goes to avoid deportation, and where a person whose benefits have been curtailed goes for recourse. In other words, vitally important disputes, involving fundamental rights and freedoms, are the province of widely disparate adjudicative bodies. There are literally hundreds of tribunals, at the federal, provincial, and municipal levels, involving thousands of full and part-time adjudicators applying a myriad of statutory schemes and regulatory regimes. If the Charter is to be Canada's "supreme law," it must have relevance for those who are most vulnerable to the adverse effects of government action (and inaction). In other words, if the Charter is to matter, it must matter in the realm of administrative justice.

\footnotetext{
${ }^{1}$ Dean and Professor, Osgoode Hall Law School. Material drawn from this paper was presented at the Osgoode Hall Law School Conference on Administrative Law and Practice, October 23, 2013, and at the CLE BC Administrative Law Conference in Vancouver on October 29, 2013, and we are grateful to the participants of those conferences for their comments and suggestions. We are also indebted to a number of colleagues who read and offered their thoughts on earlier drafts, including Benjamin Berger, Chris Bredt, Jamie Cameron, Peter Hogg, Allan Hutchinson, Grant Huscroft, Nicolas Lambert, Sheila Wildeman, and David Wright.

2 JD Candidate 2015.

${ }^{3}$ [1989] 1 SCR 1038. See, June Ross, "Applying the Charter to Discretionary Authority" (1991) 29:2 Alta L Rev 382 (on the significance of Slaight).

${ }^{4}$ See Nova Scotia v Laseur, [2003] 2 SCR 504. Paul and more recently Conway) 2010 SCC 22 [Conway].

${ }^{5}$ Doré v Barreau du Québec, 2012 SCC $12<$ http://www.canlii.org/en/ca/scc/doc/2012/2012scc12/2012scc12.html> Doré].
} 
Justice McLachlin (as she was then) seemed to anticipate this state of affairs more than a decade ago in her oft quoted dissent in Cooper $v$ Canada, ${ }^{6}$ a case which probed the extent to which tribunals had jurisdiction to consider the constitutionality of their enabling legislation. The majority in Cooper held that a human rights commission lacked the authority to decide Charter questions because its purpose and structure were not aligned with the adjudication of Charter rights. McLachlin J.'s dissent not only reached the opposite conclusion, but did so expressly on the grounds that the Charter should be relevant where people's rights were determined. It included the following memorable reference:

The Charter is not some holy grail which only judicial initiates of the superior courts may touch. The Charter belongs to the people. All law and law-makers that touch the people must conform to it. Tribunals and commissions charged with deciding legal issues are no exception. Many more citizens have their rights determined by these tribunals than by the courts. If the Charter is to be meaningful to ordinary people, then it must find its expression in the decisions of these tribunals. ${ }^{7}$

This passage was later adopted by a majority in Nova Scotia (Workers' Compensation Board) $v$ Martin, where the Court reversed Cooper and confirmed that tribunals that have the power to decide any question of law will presumptively have the power to hear and adjudicate the Charter. ${ }^{8}$

In Conway, ${ }^{9}$ the Supreme Court extended administrative jurisdiction even further by establishing that tribunals that are competent to decide questions of law also have jurisdiction not only to consider Charter issues, but also to grant Charter remedies to the extent that those remedies are consistent with their enabling legislation. Tribunals can therefore be understood as adjudicative spaces that enjoy both full access to the Charter and a broad capacity for public engagement.

In this line of case law, the Supreme Court of Canada recognized that parties could seek Charter remedies from tribunals notwithstanding the practical challenges of doing so. The Court's reticence to engage with the uneven capacity of administrative tribunals is understandable, if problematic. After all, the capacity of a tribunal or administrative decision-maker is not driven by a legislative enactment but rather executive action and can vary depending on the staffing, appointments, and resources of a particular tribunal at a particular time. That said, the capacities of a tribunal are central to the effectiveness of the Charter.

As Justice Abella observed in Tranchmontagne (a case raising similar issues to Cooper and Martin but in the context of the jurisdiction over the Human Rights Code), ensuring access to a meaningful forum for having one's rights adjudicated is a key aspect of access to justice. With respect to the Social Benefits Tribunal, she observed (in dissent):

\footnotetext{
${ }_{7}^{6}$ [1996] 3 SCR 854 [Cooper].

Ibid at para 70 .

[2003] 2 SCR 585.

Above note 6.
} 
The [Social Benefits Tribunal] is meant to be an efficient, effective, and quick process. Yet it seems to be having difficulty meeting this mandate. In 2004-2005, the SBT had a backlog of 9,042 cases and received 11,127 new appeals under the [Ontario Works Act] and the ODSPA. This Court recognized in TétreaultGadoury... that administrative bodies responsible for ensuring the payment of monetary benefits to eligible applicants would undoubtedly be impeded from this important and time-sensitive undertaking if they were asked to decide constitutional challenges.

Imposing Code compliance hearings on the SBT will similarly and inevitably impact its ability to assist the disabled community it was established to benefit in a timely way. It will be difficult to explain to the thousands of disabled individuals waiting for their appeals to be heard - many without any interim support - that there is any public benefit in the SBT hearing a complex, lengthy, and inevitably delaying jurisprudential issue with no precedential value. That is the real access issue in this case. ${ }^{10}$

A similar argument, of course, could be brought to bear on the tribunal jurisdiction to apply formal Charter rights. Practical challenges may render the Charter illusory in the context of administrative justice. For example, is it likely that a self-represented party before the Social Benefits Tribunal will properly identify a Charter issue, or have the capacity to fashion submissions based on the current jurisprudence related to a particular Charter right? How realistic is it to imagine such a party responding to the Crown's section 1 evidence? Will both legally and non-legally trained adjudicators have the capacity to manage Charter evidence? While some tribunals clearly can and are providing an appropriate forum for Charter adjudication, others seem ill-suited to the kind of Charter process designed by and for the courts in Canada.

In our view, what is needed to realize the promise of the Charter in the context of administrative justice is a Charter practice that is designed by and for administrative justice. Such a sphere of practice will need to be far more pliable and adaptable than the context of the courts. Administrative decision-makers vary with respect to procedure as well as substantive and policy expertise - some are as adversarial as courts while others adopt a more activist approach to adjudication. Some involve inquisitorial processes which place the decision-maker in the position of eliciting the necessary information from the parties. Others still are discretionary or regulatory rather than adjudicative settings. Hearings may occur electronically, over the phone, in person, or in writing. Appearances before the Human Rights Tribunal may stretch into weeks of complex evidentiary testimony while some hearings before the Landlord Tenant Board take less than thirty minutes. It is important that all these diverse contexts where Charter hearings may unfold have rules designed for a particular decision-maker's context. Many tribunals across Canada already have established Rules of Practice that guide applicants in raising constitutional matters.

10 Ibid at para 90-91. 
The Alberta Appeals Commission for Workers' Compensation Board, for instance, establishes a determined timeframe and method for raising constitutional claims:

Notice of constitutional question

3.3(1) A party who intends to raise a question of constitutional law before the Appeals

Commission relating to the distribution of powers must first provide written notice of their intention to do so, at least 14 days before the scheduled hearing date, to

(a) the Attorney General of Canada,

(b) the Minister of Justice of Alberta and the Attorney General of Alberta,

(c) the Appeals Commission, and

(d) every party.

(2) If the notice is not provided, the Appeals Commission must not consider

the constitutional question.

Referral of constitutional question to the court

3.4(1) Even when proper notice is given under rule 3.3 [Notice of constitutional question], the Appeals Commission may, instead of deciding a constitutional question relating to the distribution of powers, direct the party giving the notice to apply to the court to have the question determined, if the Commission is of the opinion that the courts the more appropriate forum in which to decide the question.

(2) If the Appeals Commission directs a party to apply to the court, the Appeals Commission must adjourn its proceeding, as it relates to the constitutional question, until the court decides the matter

The Ontario Child and Family Services Review Board's Rules of Practice outline a somewhat different approach:

Notice of Constitutional Question

35. A party who wants to challenge the constitutional validity, applicability or operability of a legislative provision must complete a notice of constitutional question which includes:

a) the name of the parties;

b) the file number;

c) the date, time and place of the scheduled hearing;

d) the specific legislative provision that is being challenged;

e) the relevant facts relied on to support the constitutional challenge;

f) a summary of the legal argument to be made in support of the constitutional challenge.

36. The party must serve a copy of the notice to the parties, to the Attorneys General of Canada and Ontario and deliver the notice to the Board at least 15 days before the question is to be argued.

37. The party must provide the original notice to the Board, together with a written statement of how and when a copy of the notice was served to the parties and to the Attorneys General. 
As Freya Kristjanson has emphasized, tribunals need to consider more than just adapting their rules to the requirements and realities of Charter litigation (including, for example, the requirement to provide Notice of Constitutional Question to the Government):

Tribunals must consider the impact that the newly expanded Charter jurisdiction has on all aspects of tribunal design. Clear procedural rules, as discussed above, are merely the first step. Adjudicator education, and adaptation of existing rules to what may be significantly more complex types of Charter litigation, will be a challenge both in terms of competence and funding. Finally, these cases may be the harbinger of a new and exciting era in administrative law, fulfilling the Chief Justice's vision of a Charter that belongs to the people, applied with full force in the administrative justice system. ${ }^{11}$

While the development of distinctive Charter rules of practice for administrative justice is in some sense a welcome response to the concern over capacity and the logistic of Charter hearings, occasions where a Charter issue is identified and argued by the parties will be rare in most tribunal settings. Charter values, as elaborated by the Supreme Court in Doré by contrast, represent a broader and far more accessible way to ensure the Charter's relevance to the sphere of administrative justice.

While the promise of Charter values under the Doré framework is apparent, its potential application gives rise to a host of important questions. ${ }^{12}$ First, how does the Charter fit within Administrative Law? Second, what are the sources of Charter values, and are the categories of Charter values set or growing? Third, what is the scope of Charter values (for example, must a Charter value be tied to a Charter right or a specific section or sections of the Charter)? Fourth and finally, how can Charter values be operationalized within the administrative justice context in a way that is coherent, transparent, predictable, and fair? This study is divided into three sections analyzing and addressing each of these questions and their implications for administrative justice.

\section{(1) Reconciling Administrative Law and the Charter}

Since the early days of Charter jurisprudence, the Supreme Court has wrestled with how to reconcile Charter and administrative law principles, particularly in the context of reviewing the

11 See Freya Kristjanson \& N. Lambek, "The Charter in Context: Applying the Charter in Everyday Administrative Decision-Making" Paper presented for $11^{\text {th }}$ Annual Charter Conference, Ontario Bar Association, November 2012 at p. 28.

12 For a discussion of the challenges to which Charter values as set out in Doré give rise, see Evan-Fox Decent \& Alexander Pless, The Charter and Administrative Law: Cross-Fertilization or Inconstancy? in Administrative Law in Context, 2nd Edition (Flood \& Sossin eds., 2012) 
exercise of administrative discretion. ${ }^{13}$ The Charter may justify intervention in administrative decisions in several different circumstances involving different degrees of discretion. ${ }^{14}$

First, a law granting discretion may be unconstitutional by its very terms. For example, a law authorizing a tribunal to grant a benefit to a defined group creates a discretion which, by its very terms, might violate section 15 of the Charter if it necessarily excludes another group from the benefit based on race, religion or one of the other enumerated or analogous grounds. For example, in $M v H$ a provision of Ontario's Family Law Act was held to be discriminatory since it granted courts the discretion to award spousal support only to heterosexual spouses and not to same-sex couples. ${ }^{15}$

The second circumstance involves a law that grants discretion to a tribunal that is not unconstitutional on its face, but such that it might nevertheless be applied in an unconstitutional manner. For example, in Eldridge v British Columbia (AG), a law authorizing the Medical Services Commission to fund certain health services was found not to violate the Charter, but the exercise of discretion by that Commission deciding not to fund interpreters for deaf patients was found to be unconstitutional. ${ }^{16}$ Similarly, in PHS Community Services Society, ${ }^{17}$ a federal Minister's discretion not to provide a statutory exemption to a safe injection site that satisfied all of the factual criteria was held to violate the Charter. The Court held that "the discretion vested in the Minister of Health is not absolute: as with all exercises of discretion, the Minister's decisions must conform to the Charter." 18

In the third circumstance, a law granting wide discretionary authority without sufficient guidance as to its application or without safeguards against arbitrary conduct might violate the procedural component of section 7 of the Charter. This basis for challenging discretion was relied upon by the majority of the Supreme Court in $R v$ Morgantaler. ${ }^{19}$ In Morgantaler, the impugned provision was a law prohibiting abortion unless a physician determined that the life or health of a woman was endangered. The procedures that therapeutic abortion committees established in hospitals to decide whether this threshold was met in individual cases were found by the majority to lack coherence, predictability, and fairness.

Fourth, a law granting a discretion that is too vague to provide sufficient notice to those who might infringe it may violate the substantive component of $\mathrm{s} 7{ }^{20}$ For example in $R v$ Morales, the

13 See especially Slaight Communications Inc v Davidson, [1989] 1 SCR 1038 [Slaight]; Ross v New Brunswick School District No 15, [1996] 1 SCR 825 [Ross]. Portions of this analysis are drawn from L Sossin, "Discretion Unbound: Reconciling the Charter and Soft Law" (2003) 45 Canadian Public Administration $465-89$. Portions of the analysis to follow are drawn from S Gratton, \& L Sossin, "In Search of Coherence: The Charter and Administrative Law under the McLachlin Court" in D Wright \& A Dodek, eds, Public Law at the McLachlin Court: The First Decade (Toronto: Irwin Law, 2011).

14 In most cases, the grounds for a Charter challenge in administrative discretion cases are based on violations of ss 2, 7, or 15 but the unconstitutional exercise of discretion might also be located elsewhere under the Charter.

$15 \quad M v H,[1999] 2$ SCR 3.

$16 \quad$ Eldridge v British Columbia $(A G)$, [1997] 3 SCR 624.

172011 SCC 44.

$18 \quad$ Ibid at para 117.

$19 \quad R v$ Morgantaler, [1988] 1 SCR 30.

$20 \quad$ See generally $R v$ Nova Scotia Pharmaceutical Society, [1992] 2 SCR 606. 
Court held that a provision granting pre-trial detention where it was justified in "the public interest" was unconstitutionally vague. ${ }^{21}$

The Supreme Court's first detailed examination of the relationship between the Charter and administrative discretion was in Slaight Communications Inc v Davidson. ${ }^{22}$ At issue in that case was a remedial discretion in the Labour Code that allowed adjudicators to resolve grievances under collective agreements. ${ }^{23}$ The grievance in Slaight concerned an allegation of wrongful dismissal. The adjudicator found that the dismissal had been wrongful and ordered the company, first, to provide the employee with a factual reference and, second, to refrain from expressing any other views about the employee. Chief Justice Dickson for the majority chose to conduct a Charter analysis and held that neither aspect of the adjudicator's order violated the Charter. Justice Lamer dissented in part and would have resolved the dispute on administrative law grounds. However, Lamer $\mathbf{J}$ wrote for the Court on the issue of the proper approach to discretionary decision-making under the Charter. He identified two kinds of discretion, each of which led to different remedies:

1. The exercise of discretion was made pursuant to legislation which confers, either expressly or by necessary implication, the power to infringe a protected Charter right.

--It is then necessary to subject the legislation to the test set out in $\mathrm{s} 1$ by ascertaining whether it constitutes a reasonable limit that can be demonstrably justified in a free and democratic society.

2. The legislation pursuant to which the exercise of administrative discretion was made confers an imprecise discretion and does not confer, either expressly or by necessary implication, the power to limit the rights guaranteed by the Charter. --It is then necessary to subject the order made to the test set out in $\mathrm{s} 1$ by ascertaining whether it constitutes a reasonable limit that can be demonstrably justified in a free and democratic society; ... ${ }^{24}$

In the circumstances of Slaight, the Court found that the Code did not require expressly or by necessary implication that a Charter right be infringed, since the arbitrator could have remedied the wrongful dismissal through other means; and therefore the Code created an imprecise discretion that permitted a Charter right to be limited. Thus, it was the order, and not the legislation, that was subjected to Charter scrutiny. ${ }^{25}$

$21 \quad$ Rv Morales, [1992] 3 SCR 711.

22 [1989] 1 SCR 1038. See, June Ross, “Applying the Charter to Discretionary Authority" (1991) 29:2 Alta L Rev 382 (on the significance of Slaight).

23 RSC 1970, c L-1, as amended by SC 1977-78, c 27, ss 21, 61.5(9) ("[w] [were an adjudicator decides pursuant to subsection (8) that a person has been unjustly dismissed, he may, by order, require the employer who dismissed him to (a) pay the person compensation not exceeding the amount of money that is equivalent to the remuneration that would, but for the dismissal, have been paid by the employer to the person; (b) reinstate the person in his employ; and (c) do any other like thing that it is equitable to require the employer to do in order to remedy or counteract any consequence of the dismissal").

$24 \quad$ Slaight, above note 39, at para 91.

25 The majority found that, while both the positive and the negative order violated the freedom of expression under s 2(b) of the Charter, each was a reasonable limit under s 1 and therefore the orders were upheld. 
The central holding of Slaight was that no public official could be authorized by a statute to breach the Charter and therefore, all discretionary authority had to be read down to only authorize decision-making which is consistent with Charter rights and guarantees. Lamer J explained this reasoning in the following terms:

\begin{abstract}
Although this court must not add anything to legislation or delete anything from it, in order to make it consistent with the Charter, there is no doubt in my mind that it should also not interpret legislation that is open to more than one interpretation so as to make it inconsistent with the Charter and hence of no force or effect. Legislation conferring an imprecise discretion must therefore be interpreted as not allowing the Charter rights to be infringed. Accordingly, an adjudicator exercising delegated powers does not have the power to make an order that would result in an infringement of the Charter and he exceeds his jurisdiction if he does so. ${ }^{26}$
\end{abstract}

Thus, discretionary authority always comes with an implied condition, which is that it be exercised in a manner consistent with all applicable Charter rights.

The principle in Slaight was applied in subsequent $\operatorname{cases}^{27}$ where the Court highlighted the overlapping nature of the Charter and administrative law analysis, observing that it was difficult to conceive of a case where a court would conclude that a decision was unconstitutional but nonetheless reasonable.

The Court confronted the dilemma of administrative discretion again in the context of Little Sisters Books and Art Emporium v Canada (Minister of Justice).28 At issue was the discretionary authority of customs officials to seize imported goods that met the obscenity test under section 163 of the Criminal Code. Justice Binnie, writing for the majority, characterized the administration of the Customs Act by customs officers as oppressive and dismissive of the appellants' freedom of expression. He concluded that the effect-whether intended or not—was to isolate and disparage the appellants on the basis of their sexual orientation.

The Court also held that, although the exercise of discretion by customs officers violated the Charter, the Customs Act provision authorizing this conduct did not. Following the Slaight approach, the majority of the Court characterized the discretion contained in the customs legislation as capable of being applied in a fashion consistent with the Charter. Therefore, the majority saw no basis to strike down the authority of customs officials to seize material on the grounds of obscenity. ${ }^{29}$

\footnotetext{
${ }^{26} \mathrm{Ibid}$ at $1077-78$

$27 \quad$ See Ross v New Brunswick School District, No 15 and Eaton v Brant County Board of Education, [1997] 1 SCR 241.

28 Little Sisters Book and Art Emporium v Canada (Minister of Justice), [2000] 2 SCR 1120 [Little Sisters].

29 See ibid at para 204 (Justice Iacobucci, writing for himself and two other members of the Court, dissented on this point. He held that the legislation itself was unconstitutional since it did not contain sufficient safeguards against unconstitutional enforcement. For the minority, simply trusting the customs bureaucracy to improve its
} 
Sometimes, the Court may apply a Charter and administrative law analysis to the same exercise of discretion. Suresh $v$ Canada ${ }^{30}$, for example, dealt with the discretionary authority of the Minister to deport refugees in circumstances where they faced the possibility of torture. ${ }^{31}$ Suresh challenged the Minister's deportation order on both Charter and administrative law grounds. A unanimous Court conducted both a Charter review of the enabling provision and an administrative review of the Minister's decision pursuant to that provision, eventually determining that the process by which Suresh was ordered deported violated his Charter rights.

With its decision in Multani $v$ Commission scolaire Maruerite-Bourgeoys ${ }^{32}$, the Court made its first effort to develop a more comprehensive approach to the dilemma of whether a Charter or administrative law analysis should apply to administrative action. Multani involved the discretionary decision of a school board to prohibit a Sikh student from wearing his kirpan, a ceremonial dagger, to school. The student and his family challenged the decision as an infringement of his freedom of religion. The Supreme Court was unanimous in allowing the challenge and striking down the board's decision but it split six to two on whether a Charter or administrative law analysis should be applied in reaching this result.

Madame Justice Charron for the majority adopted a Charter analysis since the central issue in the case was whether or not the board's decision complied with the requirements of the Charter. $^{33}$ In contrast, Deschamps and Abella JJ for the minority argued that an administrative law analysis should be conducted instead of a Charter analysis because the instrument being assessed by the Court was an administrative decision rather than a "norm of general application" such as "a law, regulation, or other similar rule of general application." 34

The majority defined the role of administrative law solely in terms of jurisdiction and warned against allowing the fundamental values protected by the Charter to be dissolved into mere administrative law principles. ${ }^{35}$ The majority position appears either to be unaware of or to discount the significant substantive role of administrative law in supervising the exercise of discretion and of public authority more broadly. It is difficult to reconcile the Multani majority's thin and one-dimensional view of administrative law with the robust view of administrative law animating earlier Supreme Court judgments, such as Baker.

administration of the Act was not enough, and they would have imposed a different decision-making structure to remedy the Charter breach).

[2002] 1 SCR 3.

312002 SCC 1 [Suresh] (paragraph 53(1)(b) of the Immigration Act gave the Minister limited discretion to deport where: the refugee's "life or freedom would be threatened" if he or she were returned to his or her country and the Minister's belief that the refugee constituted "a danger to the security of Canada" (at para 2)).

2006 SCC 6 [Multani]

33 Ibid at para 2 (the majority (Charron, McLachlin CJ, Bastarache, Binnie and Fish JJ) held that the board's decision infringed the student's freedom of religion under s 2(a) of the Charter and that the infringement could not be justified under s 1 . Justice LeBel wrote a separate opinion agreeing with the majority that a Charter analysis was appropriate but proposing that the s 1 analysis should be modified in cases involving administrative discretion, at paras 140-55).

Ibid at paras 103, 85 (the minority would have reviewed the board's decision on a standard of reasonableness and would have concluded that the decision was unreasonable in disregarding the student's freedom of religion).

$35 \quad$ Ibid at para 16 
The Court sought to synthesize the various approaches to administrative law and the Charter in Doré v Barreau du Québec. ${ }^{36}$ In Doré, the Court reviewed the decision of a provincial law society that imposed a disciplinary penalty on a lawyer for inappropriate criticism of a judge. The Court of Appeal approached Doré as a Charter case, much like Slaight, but the Supreme Court took a different approach. Justice Abella, writing for the Court, adopted an administrative law analysis to review the Quebec Barreau's decision and asserted that there is nothing in such an approach inconsistent with strong Charter protections. This approach is set out in the following terms:

The alternative is for the Court to embrace a richer conception of administrative law, under which discretion is exercised "in light of constitutional guarantees and the values they reflect" (Multani, at para. 152, per LeBel J.). Under this approach, it is unnecessary to retreat to a s 1 Oakes analysis in order to protect Charter values. Rather, administrative decisions are always required to consider fundamental values.... These cases emphasize that administrative bodies are empowered, and indeed required, to consider Charter values within their scope of expertise. Integrating Charter values into the administrative approach, and recognizing the expertise of these decision-makers, opens "an institutional dialogue about the appropriate use and control of discretion, rather than the older command-and-control relationship" (Liston, at p. 100). ${ }^{37}$

While the Court's decision in Doré may have the potential to infuse Charter values throughout administrative justice and to develop a more "robust" approach to administrative law principles, ${ }^{38}$ it remains a skeletal approach that needs to be fleshed out in the diverse contexts of administrative justice. The most important question might well be: where do Charter values come from? At first glance, this question is so straightforward as to be obvious. The source of Charter values must be the Charter itself. But this clarity quickly gives way to murk. Does every Charter right give rise to a corresponding value? Moreover, must values derive only from one or more particular rights or can they flow from underlying Charter principles that are not set out in specific rights such as human dignity? It is to this question that our analysis now turns.

\section{2) Sources of Charter Values}

According to Peter Hogg, the concept of "Charter values" existing outside or beyond the interpretation of specific Charter rights can be traced to the 1986 decision in RWDSU v Dolphin Delivery where the Supreme Court ruled that common law principles ought to be consistent with the "fundamental values enshrined in the Constitution." 39

However, the Court alluded to a concept of "Charter values" earlier that year in an entirely different context, while defining what a "free and democratic society" constitutes in $R v$ Oakes.

\footnotetext{
$36 \quad 2012$ SCC 12.

$37 \quad$ Ibid at para 35.

${ }^{38}$ Ibid at para 34.

${ }^{39}$ Peter W Hogg, "Equality as a Charter Value in Constitutional Interpretation" (2003) SCLR (2d) at 116 [Hogg].
} 
In Oakes, Chief Justice Dickson identified values such as the "respect for the inherent dignity of the human person, commitment to social justice and equality, accommodation for a wide variety of beliefs, respect for cultural and group identity, and faith in social and political institutions which enhance the participation of individuals and groups in society" as the genesis of the rights and freedoms guaranteed by the Charter. ${ }^{40}$ Interestingly, Dickson CJ adopted the approach that Charter values underlie Charter rights as opposed to the rights being the source for the values. Values in this context, in other words, temper or limit rights. For this reason, not every Charter value will accord with a specific Charter right and not every right must give rise to a specific value. $^{41}$

These references to Charter values were offered for the purpose of explaining Charter rights, rather than developing an alternative framework for aligning administrative justice and the Charter. That said, the Court has used Charter values to extend the scope of Charter rights. For instance, in Health Services and Support-Facilities Subesector Bargaining Association v British Columbia, Chief Justice McLachlin used the values identified in Oakes to give rise to a new protected right under section $2(\mathrm{~d})$ :

We conclude that the protection of collective bargaining under s. $2(d)$ of the Charter is consistent with and supportive of the values underlying the Charter and the purposes of the Charter as a whole. Recognizing that workers have the right to bargain collectively as part of their freedom to associate reaffirms the values of dignity, personal autonomy, equality and democracy that are inherent in the Charter. ${ }^{42}$

The closest the Supreme Court has come to articulating a consolidated list of Charter values was in Health Services. McLachlin CJ reaffirmed the findings in Oakes by highlighting that "human dignity, equality, liberty, respect for the autonomy of the person, and the enhancement of democracy are among the values that underlie the Charter." ${ }^{43}$ Two years after Health Services, the Court offered the following in Alberta v. Hutterian Brethren of Wilson Colony: ${ }^{44}$

The deleterious effects of a limit on freedom of religion requires us to consider the impact in terms of Charter values, such as liberty, human dignity, equality, autonomy, and the enhancement of democracy: Thomson Newspapers, at para. 125; see also Health Services and Support - Facilities Subsector Bargaining Assn. v. British Columbia, 2007

\footnotetext{
${ }^{40} R v$ Oakes, [1986] $1 \mathrm{SCR} 103$ at para $64<$ http://scc.lexum.org/decisia-scc-csc/scc-csc/scccsc/en/item/117/index.do $>$.

${ }^{41}$ See, for example, Angela Cameron and Paul Daly who argue that Chief Justice Dickson's approach to proportionality in Oakes constitutes a Charter value that must be considered by administrative decision-makers, in "Furthering Substantive Equality through Administrative Law: Charter Values in Education." On file with authors.

${ }^{42}$ Health Services and Support - Facilities Subsector Bargaining Association v British Columbia, 2007 SCC 27 at para $86<$ http://scc.lexum.org/decisia-scc-csc/scc-csc/scc-csc/en/item/2366/index.do $>$.

${ }^{43}$ As McLachlin C.J.notes, these values were also reaffirmed in $R v$ Zundel and Corbiere v Canada. See Faclities Subsector at para 81.

${ }^{44}$ Alberta v. Hutterian Brethren of Wilson Colony, 2009 SCC 37 ("Wilson Colony").
} 
SCC 27, [2007] 2 S.C.R. 391. The most fundamental of these values, and the one relied on in this case, is liberty - the right of choice on matters of religion. ${ }^{45}$

Thus, Charter values may be used to inform rights, but also to underscore the ways in which rights may be appropriately limited Charter framework. Two tribunal cases underscore this point. In the pre-Health Services case Telus Communications Inc., the Canadian Industrial Relations Board considered whether requiring employees to join a bargaining unit in the absence of a representation vote violated their freedom from compelled association. The Board relied on the Federal Court of Appeal decision International Longshore and Warehouse Union, Canada et al. v British Columbia Terminal Elevator Operators' Association to find that the right to be free from compelled association constituted a Charter value stemming from s 2(d); however, the tribunal did not cite a Charter value supporting the right to collective bargaining. Arguably, it found quite the opposite: International Longshore highlighted that the freedom to express one's "opinion and commitment to the principles of trade union solidarity by respecting the lawful picket lines of others" did not constitute a Charter value.

However, in the post-Health Services decision Certain Employees of Brandt Tractor Ltd. and IUOE, Local 115, Re, the British Columbia Labour Relations Board cited Health Services, and pursuant to the Doré framework, balanced the established right of employees not to associate under the Labour Relations Code with the value of collective bargaining and the avoidance of industrial instability in the workplace. ${ }^{46}$

The decision in Brandt Tractor demonstrates both the symbiotic relationship between Charter values and Charter rights but does little to advance a coherent framework through which to determine when a matter is better suited to Charter rights or a Charter values approach. A possible approach to this question may be traced to how the Court approached Charter values in Baker v Canada. ${ }^{47}$ In Baker, the Court decided that administrative decisions makers ought to use their discretion "in accordance with the principles of the rule of law...in line with general principles of administrative law governing the exercise of discretion, and consistent with the Canadian Charter of Rights and Freedoms." 48 The Court expanded on the need for decisionmakers to negotiate the rule of law, administrative law, and Charter principles by submitting that their "discretion must be exercised in accordance with the boundaries imposed in the statute, the principles of the rule of law, the principles of administrative law, the fundamental values of Canadian society, and the principles of the Charter." 49 While Charter rights were raised in Baker (and fully argued), the Court chose to resolve the challenge on administrative law grounds with reference to the importance of Charter values in circumscribing the exercise of administrative discretion.

\footnotetext{
45 Ibid. at para. 88.

${ }^{46}$ Certain Employees of Brandt Tractor Ltd. and IUOE, Local 115, Re [2013] BCWLD 816

$<$ http://www.canlii.org/en/bc/bclrb/doc/2012/2012canlii53287/2012canlii53287.html>.

47 [1999] 2 S.C.R. 819.

${ }^{48}$ Baker v Canada (Minister of Citizenship and Immigration), [1999] 2 SCR 817 at para 53

$<$ http://scc.lexum.org/decisia-scc-csc/scc-csc/scc-csc/en/item/1717/index.do $>$.

${ }^{49}$ Ibid at para 56.
} 
David Dyzenhaus argues that Baker advanced the concept of the "common law constitution."50 He sees the rule of law as the fundamental value that the Charter and the common law Constitution articulate but do not exhaust. ${ }^{51}$ However, it is unclear whether Dyzenhaus suggests that Charter values are subsumed within the wider principles of the rule of law or the other way around. In a subsequent paragraph, he suggests that decision makers are subject to rule of law values, which are "considered to be the fundamental or constitutional values of the society." ${ }^{2}$ At the end of the day, distinguishing Charter values from other aspects of the "common law constitution" may be a distinction with little difference. The key principle for our purposes is that Charter values should be the first recourse of an adjudicative decision-maker reviewing an exercise of discretion. Arguably, a matter should only proceed to a hearing based on a Charter right where a Charter values framework is not able to resolve the challenge at issue.

Courts and tribunals have used the passages in Baker referred to above to limit the exercise of discretion when societal and constitutional interests were at stake. For instance, the Ontario Court of Appeal in Deloitte \& Touche v Ontario (Ontario Securities Commission) ${ }^{53}$ and the Ontario Securities Commission in Re Black ${ }^{54}$ invoked the passages in Baker to rule that the Commission's statutorily-conferred discretion to authorize disclosure in the public interest was restricted by the Charter. The OSC in Re Black relied on Charter values in its analysis to determine the extent to which disclosure implicated the public interest. ${ }^{55}$

However, the requirement to consider constitutional principles created inconsistencies in applying the Charter in administrative realms. In Lalonde $v$ Ontario, consistent with the approach the Supreme Court adopted in Baker, the OCA ruled that the Health Restructuring Commission was obligated to consider the constitutional principles of "respect for and protection of minorities" in exercising its discretion to downscale health services. ${ }^{56}$ As the OCA notes:

If the values of an international convention not adopted in statute form by Parliament have a bearing on the validity of the exercise of ministerial discretion, it must be the case that failure to take into account a fundamental principle of the Constitution when purporting to act in the public interest renders a discretionary decision subject to judicial review ${ }^{57}$

\footnotetext{
${ }^{50}$ David Dyzenhaus, “Constituting the Rule of Law: Fundamental Values in Administrative Law” (2002) 27 Queen LJ 445 at 448.

${ }^{51}$ Ibid at 498 .

${ }^{52}$ Ibid at 499.

${ }^{53}$ Deloitte \& Touche LLP v Ontario (Securities Commission) (2002), 159 OAC 257 at para 29 $<$ http://www.canlii.org/en/on/onca/doc/2002/2002canlii44980/2002canlii44980.html>.

${ }^{54}$ Re Black (2007), 31 OSCB 10397.

${ }^{55}$ Ibid at paras 87-8.

${ }^{56}$ Lalonde v Ontario (Health Services Restructuring Commission) (2001), 56 OR (3d) 577 at para 173 $<$ http://www.canlii.org/en/on/onca/doc/2001/2001canlii21164/2001 canlii21164.html>.

${ }^{57}$ Ibid at para 179 .
} 
However, the Ontario Superior Court in Tremblay v. Lakeshore (Town) held that a municipality was not obliged to consider the interests of the French linguistic minority because "the case is to be determined on traditional administrative law principles rather than constitutional analysis." 58 While the issue here may simply be semantics (the difference between a discretionary decisionmaker being "obligated" to consider constitutional principles as opposed to the failure to consider such principles giving rise to a prima facie case of unreasonableness), the outcome of a case may turn on such characterizations. In light of Doré, however, the importance of a bright line between administrative law and constitutional principles may be diminishing.

Notwithstanding this apparent ambivalence to incorporating constitutional principles within an administrative law analysis, it is apparent from the above review that the courts have recognized at least four sources for Charter values: Charter rights (e.g. expressive freedom, equality), unwritten Constitutional Principles (e.g. the rule of law and respect for minorities), principles arising from the courts' Charter analysis (e.g. human dignity, privacy); and common law constitutional principles (e.g. fairness). In each case, while the analysis may begin with constitutional sources, it is brought to life through administrative justice.

Peter Hogg, as noted above, has argued that every Charter right likely has a corresponding Charter value, although this view has not been adopted by the courts. ${ }^{59}$ David Dyzenhaus's discussion of Charter values in Baker adopts the premise that the Charter has made more explicit the fundamental values that underlie the "common law constitution," discussed above. ${ }^{60}$ Charter values may also flow from the preambular language reflecting commitments to the rule of law and supremacy of God. We suggest that there may well be multiple sources for Charter values - as the Charter both extended and reflected Canada's constitutional commitments. The more difficult task, as discussed below, is deciding what is not a Charter value - and why.

While recognizing the importance of Charter values in Doré v Barreau du Quebec, the Court did not explore or elaborate upon the source of those values or their boundaries. They are simply assumed to exist and to form a knowable conceptual framework to guide discretionary decisionmaking. ${ }^{61}$ Since the Court in Doré did not provide a definitive list of values that are to inform administrative law decisions, previous jurisprudence and tribunal decisions may be of assistance. It is to this task that we now turn.

\footnotetext{
${ }^{58}$ Tremblay $v$ Lakeshore (Town) (2003), 179 OAC 123 at para 21

$<$ http://www.canlii.org/en/on/onscdc/doc/2003/2003canlii6354/2003canlii6354.html>

${ }^{59}$ Hogg, supra note 1 at 117.

${ }^{60}$ Dyzenhaus, supra note 5 at $453,489$.

${ }^{61}$ Doré v Barreau du Québec, 2012 SCC 12 at $6<$ http://www.canlii.org/en/ca/scc /doc/2012/2012scc12/2012scc12.pdf>
} 


\section{(2) The Scope of Charter Values}

As Nicolas Lambert has observed, the main problem with attempting to reconcile the various references to Charter values across disparate cases is the lack of precise definition or explanation as to what is or is not a Charter value and why. ${ }^{62}$ While any attempt to map the terrain of Charter values must necessarily be a tentative enterprise in light of this ambiguity, we argue that clarifying the scope of Charter values is essential to ensuring their coherent and principled application in the administrative justice context.

One approach to Charter values (in the sense the term was used in the context of administrative justice in Doré) is that this refers to a method of applying Charter rights. In other words, unlike the situation where a Court (or tribunal) adjudicates a Charter challenge featuring the adversarial presentation of evidence, the shifting onus of proof under s 1 and an Oakes analysis, etc, a Charter values approach obviates this formal methodology in favour of an administrative law balancing of the Charter right at issue and the statutory objectives. On this view, the scope of Charter values is simply the various rights set out in the section of the Charter ${ }^{63}$ In Doré, for example, the value at issue was expressive freedom, and its scope is as set out in s 2(b) of the Charter. A Charter values methodology could similarly be applied to the rights set out in s.15, s.7 and so forth. This approach has the value of clarity and transparency, but also appears to use a term "Charter values" that has been deployed to convey something different than simply the text of the Charter rights themselves. When the Court refers to the importance of Charter values in interpreting and developing the common law, for example, the Court has indicated such values included "human dignity" and the "values enshrined in the Charter."64

The courts have recognized a number of Charter values in common law and Constitutional settings. Will all these values be applicable to the context of administrative justice? While it is premature to attempt to map the entire terrain of Charter values in the context of administrative justice, those Charter values already recognized by the courts likely will serve as a point of departure. More importantly, the methodology employed by the courts in developing Charter values in judicial settings may shed light on how the scope of such values may be applied by administrative decision-makers.

Below, we set out a non-exhaustive list of the Charter values which have been variously mentioned or elaborated by Courts, some of which parallel specific Charter rights, and some of which go beyond the specific text of the Charter.

\footnotetext{
${ }^{62}$ Correspondence with one of the authors and Professor Lambert, January 24, 2013, on file with authors. See also N. Lambert, "The Charter in the Administrative Process: Statutory Remedy or Refounding of Administrative Jurisdiction?" (2007) 13 Rev. Const. Stud. 21.

${ }^{63}$ We are grateful to discussions with David Wright for fleshing out this approach to the scope of Charter values.

${ }^{64}$ R. v. Salituro [1991] 3 S.C.R. 654.
} 


\section{Liberty}

As the Chief Justice asserted in the Wilson Colony decision, "liberty" is perhaps the most significant Charter value. Liberty has been discussed as a Charter value in at least two senses. First, in the positive sense, liberty has been framed as an expression of individual choice. Second, liberty has been used in the negative sense, as freedom from interference by the state. Justice Bertha Wilson addressed "liberty in the context of the values underlying the Charter in her concurring reasons in Morgantaler. ${ }^{65}$

The idea of human dignity finds expression in almost every right and freedom guaranteed in the Charter. Individuals are afforded the right to choose their own religion and their own philosophy of life, the right to choose with whom they will associate and how they will express themselves, the right to choose where they will live and what occupation they will pursue. These are all examples of the basic theory underlying the Charter, namely that the state will respect choices made by individuals and, to the greatest extent possible, will avoid subordinating these choices to any one conception of the good life.

Thus, an aspect of the respect for human dignity on which the Charter is founded is the right to make fundamental personal decisions without interference from the state. This right is a critical component of the right to liberty. Liberty, as was noted in Singh, is a phrase capable of a broad range of meaning. In my view, this right, properly construed, grants the individual a degree of autonomy in making decisions of fundamental personal importance...

Liberty in a free and democratic society does not require the state to approve the personal decisions made by its citizens; it does, however, require the state to respect them. ${ }^{66}$

While Justice Wilson's view of liberty did not attract majority support in Morgantaler, similar formulations have been adopted by the Court in discussing the value of liberty in subsequent cases, particularly as part of the section 1 justification analysis.

In Wilson Colony, the Court considered whether a religious community's freedom of religion was infringed by a requirement that photos accompany an application for a driver's license. ${ }^{67}$ The Chief Justice, as noted above, recognized that in determining whether an infringement is justified, the Court should consider not just Charter rights but the values underlying those rights, of which the most important is "liberty." Because the incidental effect of the photo requirement for driver's licenses was not to preclude religious practice but rather to impose a cost on religious practice (where transportation options other than driving would have to be pursued), it constituted a reasonable limit. Had the incidental impact been to preclude the practice of a

\footnotetext{
${ }^{65}$ [1988] 1 S.C.R. 30.

${ }^{66}$ Ibid at 166-7. This passage was cited with approval by lacobucci J. in R. v. Salituro, supra note , in elaborating the application of Charter values to the development of the common law.

${ }^{67}$ Supra note.
} 
religious ritual or sacrament, as the ban on kirpans in schools at issue in Multani implicated, the Court would presumably have come to the opposite conclusion based on the liberty value.

While the Court's recourse to values such as liberty as part of the section 1 analysis has been incorporated into the Oakes framework of analysis, it remains to be worked out how such values will inform the balancing envisioned in Doré, At a minimum, the Court's examination of the Charter value of liberty suggests these values will be treated as a spectrum rather than an absolute point or bright line for purposes of such balancing. This is particularly relevant for administrative justice where nearly every statutory tribunal or regulatory agency includes within its mandate the adjudication of state interference in the freedom of people to pursue their own choices.

\section{Human Dignity}

The value of human dignity is invoked often in Charter jurisprudence but rarely explored. ${ }^{68}$ As noted above in Justice Wilson's reasons in Morgantaler, it is described as a value informing nearly all Charter rights. Additionally, it is referred to as a Charter value in Hill $v$ Church of Scientology. ${ }^{69}$ While examining the value of freedom of expression, discussed below, Cory $\mathrm{J}$ submits that "the good reputation of the individual represents and reflects the innate dignity of the individual, a concept which underlies all the Charter rights." "70 That said, Cory J. was also careful to emphasize that the application of Charter values to such as human dignity to common law rules is not the same as expanding the application of the Charter itself to all private action, and in so doing attempted the distinguish Charter rights from Charter values. Cory J. explained:

The most that the private litigant can do is argue that the common law is inconsistent with Charter values. It is very important to draw this distinction between Charter rights and Charter values. Care must be taken not to expand the application of the Charter beyond that established by s. 32(1), either by creating new causes of action, or by subjecting all court orders to Charter scrutiny. Therefore, in the context of civil litigation involving only private parties, the Charter will "apply" to the common law only to the extent that the common law is found to be inconsistent with Charter values. ${ }^{71}$

We believe a similar approach underlies Doré. Human dignity has arisen not just in the expressive context but in a variety of other Charter settings. Where an exercise of discretion appears to undermine this value, should this be included within the scope of Charter values to which an administrative decision-maker ought to consider? Pearl Eliadis, for example, has

\footnotetext{
${ }^{68}$ For discussion, see L. Sossin, "The 'Supremacy of God', Human Dignity and the Charter of Rights and Freedoms" (2003) 52 University of New Brunswick Law Journal 227-41.

${ }^{69}$ Hill v. Church of Scientology of Toronto, [1995] 2 S.C.R. 1130 See also WIC Radio Ltd. v. Simpson 2008 SCC 40 at para. 79 .

${ }^{70} \mathrm{Ibid}$ at para 120.

${ }^{71}$ Ibid. at para. 95.
} 
argued that cases concerning poverty law should be informed by the "Charter-inspired value" of human dignity. ${ }^{72}$

If human dignity is within the scope of Charter values, then Charter values may become overbroad, inchoate and difficult to apply coherently. If human dignity lies outside the scope of Charter values, however, then a two tier approach to the Charter may develop, with Courts pursuing a broad approach to the term while administrative adjudicators would be limited to a narrow approach. Given that what is at issue in the application of Charter values in administrative justice is an administrative law balancing, not a specific invalidation of any government action, then we would suggest the broader approach is more appropriate. Subject to judicial review on reasonableness grounds as envisioned in Doré, it should be for administrative decision-makers and adjudicators to determine the range of Charter values which have application in the context of their specialized context. Yet, the open-ended and unchartered nature of such a value raises important concerns. How will parties and their advocates anticipate the ways in which a value as diffuse as "human dignity" might factor into the decision-making process? Will it mean something similar in a social benefits context as a prison or hospital context? Operationalizing values such as human dignity poses far more challenging dilemmas than recognizing those values, as we explore further in the final section of this study.

\section{Equality}

Equality is a value that has underpinned decisions dealing with a variety of Charter rights, and also is set out as a specific guarantee in s.15 of the Charter. The extensive reference to the equality value lends support to Angela Cameron and Paul Daly's view that it constitutes a fundamental principle of the constitution, akin to those unwritten constitutional principles elaborated in the Secession Reference. ${ }^{73}$ In other words, the Charter value of equality goes well beyond the specific elaboration of the equality right under s.15. For example, Peter Hogg outlines several cases concerning freedom of association, the right to vote, and principles of fundamental justice that are premised on the value of equality. ${ }^{74}$

The equality value has been used in common law settings as well. In MacCabe v Board of Education, for example, the Alberta Court of Appeal ruled that the common law guiding tort remedies should try to be consistent with Charter values, which includes "equality." Equality also has been referenced in administrative justice settings. In Ismail v British Columbia (Human Rights Tribunal), for example, the BC Superior Court employed a Doré analysis to balance the values of equality and free expression.

\section{Autonomy}

\footnotetext{
${ }^{72}$ For further discussion, see L. Sossin, "The 'supremacy of God', Human Dignity and the Charter of Rights and Freedoms” (2003) 52 University of New Brunswick Law Journal 227-41.

${ }^{73}$ Cameron and Daly, supra note 3 at 19.

${ }^{74}$ Hogg, supra note 1 at 121, 122, 126-130.
} 
Personal autonomy is a Charter value that has been used as an interpretive guide in common law settings. ${ }^{75}$ Here again, while captured in specific rights such as the right to be free from unreasonable search and seizure in s. 8 of the Charter, autonomy extends beyond this and any other specific Charter right as well. For example, the Supreme Court in $R v$ Salituro suggested that the common law rule invalidating the competence of a spousal witness in the context where the spouses are irreconcilably separated was inconsistent with Charter values, specifically that "individual choices [should] not be restricted unnecessarily."

Iacobucci J., writing for the Court, explained the relevance of Charter values as follows:

Where the principles underlying a common law rule are out of step with the values enshrined in the Charter, the courts should scrutinize the rule closely. If it is possible to change the common law rule so as to make it consistent with Charter values, without upsetting the proper balance between judicial and legislative action that I have referred to above, then the rule ought to be changed. The common law rule making an irreconcilably separated spouse an incompetent witness for the prosecution against the other spouse is inconsistent with the values in the Charter. Subject to consideration of the limits on the judicial role, the rule ought therefore to be changed. Society can have no interest in preserving marital harmony where spouses are irreconcilably separated because there is no marital harmony to be preserved. ${ }^{77}$

Mayo Moran has used Salituro to explain the importance of Charter values as a guide to the interpretation and application of the common law. For example, in addition to Iacobucci's concerns over autonomy, the common law rule was premised on an anachronistic view of women and an exaggerated emphasis placed on the promotion of marital harmony. ${ }^{78}$ In this respect, the common law rule clashed with the equality values enshrined in the Charter. ${ }^{79}$ Moran uses this example to stress the need to look beyond specific guarantees in the Charter when interpreting the common law, in favour of a reading that is in accordance with the "basic underlying theory of the Charter". ${ }^{80}$ From this standpoint, autonomy and equality values speak to the broader, more fundamental values of the Charter; it is against these underlying values that the common law develops. ${ }^{81}$

This connection is not unique to autonomy and equality. While specific Charter rights are distinct, many Charter values should be seen as mutually reinforcing and interlocking. This adds both the coherence of Charter values in administrative justice, but also to their complexity and variability.

\footnotetext{
${ }^{75}$ MacCabe v Board of Education of Westlock Roman Catholic Separate School District, 2001 ABCA 257 at para 106.-7< http://www.albertacourts.ca/jdb/1998-2003/ca/Civil/2001/2001abca0257.pdf $>$.

${ }_{77}^{76} R$ v Salitburo, [1991] 3 SCR $654<$ http://www.canlii.org/en/ca/scc/doc/1991/1991 canlii17/1991canlii17.html $>$.

77 lbid.

${ }^{78}$ Mayo Moran, "Authority, Influence, and Persuasion: Baker, Charter values and the Puzzle of Method" in The

Unity of Public Law, David Dyzenhaus, ed (Toronto: Hart, 2004) at 417.

${ }^{79}$ lbid at 418.

${ }^{80}$ Ibid.

${ }^{81}$ Ibid.
} 


\section{Fairness}

In addition to the Charter values expressed above, numerous courts and commentators have noted values stemming from common law rules concerning process. The Charter value of fairness is particularly applicable to the sphere of administrative justice, where procedural fairness has universal relevance.

Robert Currie notes that the Charter values of procedural fairness and a fair trial, embodied within sections 7 and $11(\mathrm{~d})$, inform the common law rules of evidence. ${ }^{82}$ Currie goes on to demonstrate that other common law rules of defence, such as confession rules and the ability to make a full answer of defense, have been "constitutionalized" through their intersection with "Charter standards." ${ }^{83}$ Kent Roach expands upon this point by demonstrating that the common law rules relating to admissibility of evidence were modified in $R v$ Seaboyer in order to be consistent with Charter values. ${ }^{84}$ He notes that other common law presumptions such as fairness and respect for international commitments to human rights reflect Charter values, whereas common law presumptions such as the right to property have lost their resonance in the Charter era. ${ }^{85}$

The decisions in Hennessy v Horse Racing Alberta and Gonzalez v Alberta Driver Control Board affirm Roach and Currie's findings that procedural fairness and common law rules of evidence arguably are informed by Charter values as well. ${ }^{86}$ In Hennessy, the Queen's Bench reviewed an appeal from the Tribunal of Horse Racing Alberta. The court found that the claimant was denied procedural fairness and fundamental justice because he was unable to make a full answer and defence, which the court considered a Charter value. ${ }^{87}$

Finally, the Quebec Court of Appeal recently described "natural justice" as a Charter value emanating from s 7 of the Charter. In Syndicat des travailleuses et travailleurs de ADF - CSN v Syndicat des employés de Au Dragon Forgé Inc, the Quebec Court of Appeal applied Doré to balance the objective of a law that sought to maintain confidentiality in disciplinary boards with the value of natural justice. ${ }^{88}$

\footnotetext{
${ }^{82}$ Robert J Currie, "The Evolution of the Law of Evidence: Plus Ça change ...?” (2011) 15 Can Crim L Rev 213 at 222.

${ }^{83}$ Ibid.

${ }^{84}$ Kent Roach, Constitutional Remedies in Canada 2 ed, Release No 19, December 2012. Toronto: Canada Law Book, 2012 at para 14.780.

${ }^{85}$ Kent Roach "Common Law Bills of Rights as Dialogue between Courts and Legislatures" (2005) 55 UTOR L J 733 at $747-8$.

${ }^{86}$ See also $A(L L) v B(A)$ or $R v O^{\prime}$ Connor.

${ }^{87}$ Hennessy v Horse Racing Alberta, 2006 ABQB 903 at para $28<$ http://www.canlii.org/en/ab/abqb/doc/2006/2006abqb903/2006abqb903.html>.

${ }^{88}$ Syndicat des travailleuses et travailleurs de ADF - CSN v Syndicat des employés de Au Dragon forgé Inc, 2013 QCCA 793 at para 45.
} 


\section{Expressive Freedom}

The Supreme Court has identified "freedom of expression" as a Charter value. In its decisions concerning defamation, ${ }^{89}$ journalist-sourced privilege, ${ }^{90}$ and picketing ${ }^{91}$ the Court has used the Charter value of freedom of expression in order to rule on the validity of the common law in the Charter era. The use of the value was most recently applied by the Ontario Court of Appeal. In Jones $v$ Tsige, the Court of Appeal balanced the right to privacy with the Charter value of freedom of expression. ${ }^{92}$

Expressive freedom has also been applied in the context of administrative justice. In Goldberg $v$ Law Society (British Columbia), the British Colombia Court of Appeal discussed whether the Charter value of "freedom of expression" was engaged in a disciplinary hearing case. The court highlighted the Charter value of freedom of expression, opposed to the Charter right of 2(b), because "we [the court] do not have a Charter issue squarely before us." 93 Freedom of expression as a Charter value was confirmed in Pridgen $v$ University of Calgary, where the court rejected the findings of the Review Committee and Board of Governors on the basis that it made no attempt to balance the statutory mandate with the right of freedom of expression. ${ }^{94}$ While the court discussed freedom of expression in light of Charter rights and statute, its discussion of Charter values and application of Doré support the contention that freedom of expression constitutes a Charter value.

This value has been applied even more clearly by the Ontario Human Rights Tribunal in Taylor-Baptiste v. Ontario Public Service Employees Union, ${ }^{95}$ and Marceau v. Brock University. ${ }^{96}$ In these cases, the Tribunal used reference to Charter value of expressive freedom as a tool in interpreting the Code.

Most significantly, of course, expressive freedom was at issue in the Doré decision itself. Abella J. recognized that, "in dealing with the appropriate boundaries of civility, the severity of the conduct must be interpreted in light of the expressive rights guaranteed by the Charter, and, in particular, the public benefit in ensuring the right of lawyers to express themselves about the

\footnotetext{
${ }^{89}$ Hill v Church of Scientology of Toronto, [1995] 2 SCR $1130<$ http://scc.lexum.org/decisia-scc-csc/scc-csc/scccsc/en/item/1285/index.do>; Grant v Torstar Corp, 2009 SCC 61< http://scc.lexum.org/decisia-scc-csc/scc-csc/scccsc/en/item/7837/index.do $>{ }^{89}$

${ }^{90} R v$ National Post, 2010 SCC $16<$ http://scc.lexum.org/decisia-scc-csc/scc-csc/scc-csc/en/item/7856/index.do $>$.

${ }^{91}$ RWDSU v Pepsi-Cola Canada Beverages, [2002] 1 SCR 156 at paras 106-7 <http://scc.lexum.org/decisia-scc$\mathrm{csc} / \mathrm{scc}-\mathrm{csc} / \mathrm{scc}-\mathrm{csc} / \mathrm{en} / \mathrm{item} / 1945 /$ index.do $>$.

${ }_{93}$ Goldberg $v$ Law Society (British Columbia), 2009 BCCA 147 at para 57.

${ }^{93}$ Goldberg v Law Society (British Columbia), 2009 BCCA 147 at para 57.

Pridgen $v$ University of Calgary, 2012 ABCA 139 at paras 126, 176

$<$ http://www.canlii.org/en/ab/abca/doc/2012/2012abca139/2012abca139.html $>$.

2013 HRTO 180 at paras. 31-35.

${ }^{96} 2013$ HRTO 569 at para. 13-15. See also R.C. v. District School Board of Niagara, 2013 HRTO 1382 (CanLII), <http://canlii.ca/t/g034z>
} 
justice system in general and judges in particular." ${ }^{97}$ The Court concluded that in light of the egregious content and tone of the lawyer's complaint about the Judge, the Court's balancing of expressive freedom with the statutory objectives of the Barreau's Code of Ethics "cannot be said to represent an unreasonable balance....98

\section{Privacy}

Privacy represents yet another Charter value which is likely to find application in administrative justice contexts and which exists outside of the context of a specific Charter right. In M. (A.) v. Ryan,${ }^{99}$ the Supreme Court employs Charter values to extend the scope of common law privilege to reflect changing "social and legal realities of our time," and in particular the privacy of victims of sexual violence who seek psychiatric counselling. ${ }^{100}$

In Gore v College of Physicians \& Surgeons (Ontario), for example, the appellant physicians disputed an investigation by the Registrar of the College of Physicians and Surgeons pursuant to the Regulated Health Professions Act. The appellants argued that the regulation (and presumably, decisions made pursuant to the regulation) should be interpreted in light of the Charter values of protection of patient privacy and protection against self-incrimination. The court ultimately chose not to invoke Charter values in deciding the case since the regulation was not ambiguous and a Charter values approach was thus unnecessary. ${ }^{101}$ However, the court neither confirmed nor disputed the existence of the Charter values raised.

\section{Conclusion}

The list above is not exhaustive, and should be seen as dynamic rather than static aspect of the Charter's application to administrative justice. We recognize that the scope of Charter values set out above is a somewhat subjective account of an ill-defined category. Other possible Charter values could be added, including, for example, mobility, mentioned in the context of Khadr $v$ Canada. In that case, the Federal Court [FC] reviewed the Government's decision to refuse Omar Khadr's request for a passport. The FC ruled that the "right to leave Canada is a sufficiently important aspect of an individual's freedom" and constituted a Charter value. ${ }^{102}$ The Court also argued that the issuance of a passport reflects the Charter value expressed by mobility rights. ${ }^{103} \mathrm{We}$ viewed this value as simply overlapping the mobility right as opposed to a distinct value that could constrain discretion or guide statutory interpretation.

\footnotetext{
${ }^{97}$ Doré supra note, at para. 63.

98 Ibid. at para. 71.

99 [1997] 1 S.C.R. 157.

100 Ibid at para. 21.

${ }^{101}$ Gore v College of Physicians \& Surgeons (Ontario), 2009 OCA 546 at para 30 $<$ http://www.canlii.org/en/on/onca/doc/2009/2009onca546/2009onca546.html >.

${ }^{102}$ Khadr v Canada (Attorney General) 2006 FC 727 at para 69 $<$ http://www.canlii.org/en/ca/fct/doc/2006/2006fc727/2006fc727.html >.

${ }^{103} \mathrm{Ibid}$ at para 113 .
} 
Similarly, the Supreme Court in Multani highlighted the promotion of multiculturalism and diversity as consistent with the Charter although it did not characterize them as Charter values per se. ${ }^{104}$ Even if not elevated to the status of a Charter value, in Lalonde, as noted above, the Ontario Court of Appeal held that respect for and protection of minorities constituted an unwritten constitutional principle. ${ }^{105}$ Similarly, democracy was recognized as an unwritten constitutional principle in the Secession Reference, ${ }^{106}$ and invoked as a Charter value in Wilson Colony as set out above. While mobility is arguably too narrow to constitute a Charter value, multiculturalism and the enhancement of democracy may be overly broad to fulfill this function. Alternatively, it may be that values such as mobility and multiculturalism are still inchoate and through further refinement and development may be recognized as within the scope of Charter values delineated above.

Notwithstanding its tentative nature, we believe the scope of Charter values discussed above in Charter jurisprudence represents an important point of departure for the development of Charter values for administrative justice. While Charter values may be seen as limited simply to the text of Charter rights differently applied in administrative justice settings, this does not appear to be how the courts themselves have conceived of Charter values, nor would such a formalist approach be in keeping with the robust and adaptive administrative law framework invoked in Doré. That said, many of the values set out lack an important contextual dimension.

Administrative justice, unlike courts, must also take into consideration the policy mandate of a particular decision-making body and the purposive nature of statutory or prerogative authority. As the Supreme Court recognized in the context of Charter remedies in Conway, while a court may do anything that is "just and appropriate" pursuant to section 24(1) remedies, a tribunal could only remedy Charter breaches by recourse to their statutorily mandated powers. The Charter cannot, in other words, be used by a tribunal to frustrate or usurp the role of the legislature in demarcating the boundaries of that tribunal's authority or its reasons for being. A similar conceptual framework, we suggest, applies in the context of Charter values. While the Charter jurisprudence can shed light on the scope of Charter values, it remains for each tribunal to determine which Charter values will be relevant to its mandate, and how to balance those values against its policy mandate. For example, while personal autonomy may be a broadly recognized Charter value, it will necessarily mean something different in the context of a

\footnotetext{
${ }^{104}$ Multani $v$ Commission scolaire Marguerite-Bourgeoys, 2006 SCC 6 at para $78<$ http://scc.lexum.org/decisiascc-csc/scc-csc/scc-csc/en/item/15/index.do $>$. For discussion, see Vaughan Black, "Cultural Thin Skulls" 60 UNB LJ 186 at 203-4.

${ }^{105}$ Lalonde, supra note 11 at 187-8. See also Chief Justice Dickson's reference to "Canada's commitment to the values of equality and multiculturalism enshrined in ss 15 and 27 of the Charter" in Canada (Human rights commission) v Taylor, [1990] 3 SCR 892 and "respect for cultural and group identity" as a Charter value mentioned in Ross, supra note 13. On the implications of unwritten constitutional principles more generally, see Jean Leclair, “Canada’s Unfathomable Unwritten Constitutional Principles” (2002) 27 Queen's LJ 389.
}

${ }^{106}$ [1997] 3 SCR 3. 
privacy commission than a parole board. The variability in the application of Charter values mirrors the variability of other administrative law frameworks (for example, procedural justice) as discussed further below. In other words, in the administrative justice sphere, variability may be part of the solution, not the problem.

While statutory and policy context are distinctly important for any analysis of the scope of Charter values in an administrative justice context, the Charter must continue to be a mechanism for advancing broader rights than those contained in a particular statutory or policy context. Charter values, in this sense, provide a bridge between fundamental and core values on the one hand, and the choices legislatures and executive government make on the other. Determining the scope of Charter values requires being attentive to both these dynamics in the diverse contexts of administrative justice. Further, the dilemmas accompanying the power or unelected judges to further policy aims and constrain democratic action through judicial review does not apply in the context of administrative justice. ${ }^{107}$ Here, the Charter cannot negate or "trump" legislative choices, but rather is used to inform, refine, focus and interpret those choices.

In light of the analysis above, our discussion turns to how administrative decision-makers (and the courts which review those decisions) may operationalize Charter values in a fashion that is coherent, transparent, consistent, workable, and principled.

\section{(3) Operationalizing Charter Values}

After Doré, the Supreme Court confirmed that tribunals have the opportunity to imbue their decisions regarding the exercise of administrative discretion with Charter values and engage in a more active form of constitutional interpretation. At the same time, Charter values remain an important tool of statutory interpretation where competing approaches to a statutory power are available. In still other cases, Charter values may inform how common law rules are interpreted and applied. Charter values in each of these contexts will be relevant to administrative justice. How can the consistency and coherence of these interpretations of Charter values be assured? In short, how can Charter values be developed through administrative justice decision-making? Is it open to tribunals to identify new Charter values or extend existing ones? In this section, we examine how administrative justice decision-makers have approached the task of delineating and operationalizing Charter values.

In Re Black, the OSC considered whether the right against self-incrimination and the right to make a full answer and defence constituted Charter values. ${ }^{108}$ The OSC attempted to balance these competing values by considering their merits and how the privileging of one would

\footnotetext{
${ }^{107}$ For a summary of these dilemmas, see Grant Huscroft and Ian Brodie, Constitutionalism in the Charter Era (Toronto, Lexis-Nexis, 2004). See also Grant Huscroft, "Constitutionalism from the Top Down" (2007) 45 Osgoode Hall Law School 91.

${ }^{108}$ Re Black, supra note at para 191.
} 
compromise the other. However, the Commission did not offer a definitive test to help us reconcile these values in the end. ${ }^{109}$

Since Doré, tribunals have yet to achieve greater methodological clarity. For example, in $R C v$ District School Board of Niagara, the Human Rights Tribunal of Ontario granted the Canadian Civil Liberties Association intervenor status for the purposes of discussing "how values of the [Charter] including s 2(a) (freedom of religion) and s 15("equality") should inform the interpretation of the Code" in question. ${ }^{110}$ While one can surmise that both "equality" and "freedom of religion" were Charter values for the purposes of $R C$, the case did not crystalize a method for testing the existence of these values in future cases. In Certain Employees of Brandt Tractor Ltd. and IUOE, Local 115, Re, mentioned above, the British Columbia Labour Relations Board applied Doré in considering employees' applications for partial decertification from their union under the Labour Relations Code. ${ }^{111}$

Operationalizing Charter values should be seen as part of a model of administrative justice referred to as "active adjudication." 112 This form of more flexible adjudication may be particularly important in contexts where one or more parties often will have no legal representation and where adjudicators often will not have legal training. Tribunals are less constrained by an adversarial model of adjudication, and have developed methods to accommodate the challenges that vulnerable parties coming before the tribunal may experience. In the context of Charter values, this more effective and efficient model may involve the adjudicators identifying rights issues where the parties do not have the background or capacity to do so and taking steps to obtain the information or submissions necessary to adjudicate them. This may involve mechanisms that range from retaining amicus counsel to engaging in inquisitorial questioning, or developing interpretive guidelines upon which parties and decisionmakers can rely. ${ }^{113}$

\footnotetext{
${ }^{109}$ Ibid at paras 174-93.

${ }^{110}$ RC v District School Board of Niagra, 2012 HRTO 1591 at para 8

$<$ http://www.canlii.org/en/on/onhrt/doc/2012/2012hrto1591/2012hrto1591.html $>$.

${ }^{111}$ Certain Employees of Brandt Tractor Ltd. and IUOE, Local 115, Re [2013] BCWLD 816 $<$ http://www.canlii.org/en/bc/bclrb/doc/2012/2012canlii53287/2012canlii53287.html>.

${ }^{112}$ Active adjudication does not have a precise definition but usually connotes a mid-point between adversarial and inquisitorial models of adjudicative hearings. An active adjudicator will respect the right of parties to put forward their own positions on questions of law and fact but may supplement submissions by raising additional issues, seeking information or perspectives not provided by the parties, and redressing any asymmetries resulting from represented and unrepresented parties or parties of greater or lesser sophistication. The active adjudicator relies for guidance on the statutory objectives of administrative justice and how those objectives could most effectively be fulfilled through the adjudicative process. For a discussion of active adjudication, see L. Sossin and S. Green, "Administrative Justice and Innovation: Beyond the Adversarial/Inquisitorial Dichotomy" in L. Jacobs \& S. Bagley (eds.), The Nature of Inquisitorial Processes in Administrative Regimes: Global Perspectives (Surrey: Ashgate, 2013) (forthcoming).

${ }^{113}$ See S Green \& L Sossin, “Administrative Justice and Innovation: Beyond the Adversary/Inquisitorial Dichotomy” in L. Jacobs \& S. Bagley (eds.), The Nature of Inquisitorial Processes in Administrative Regimes: Global Perspectives (Surrey: Ashgate, 2013) for further discussion of this range of mechanisms.
} 
The methodology by which administrative decision-makers might integrate Charter values dates back to Slaight and is fairly straightforward. So, for example, where two interpretations are open to a tribunal member and one will advance a Charter value more so than other interpretations, it should be preferred. When a statute's meaning remains ambiguous, Charter values may be employed to inform the statutory language. ${ }^{114}$ Given the diversity of settings and variety of Charter values elaborated above, however, a more textured methodology may be required to give effect to the application of Charter values to administrative discretion in Doré. We suggest the following approach as an example of such a methodology.

\section{1) Discretionary authority or interpretive scope;}

First, the administrative decision-maker needs to identify a discretionary power, or a question of interpretation to which more than one approach would be plausible. As the courts have made clear in developing Charter values, this situation arises only where a decision-maker is exercising discretion. This is an important constraint on administrative decision-makers applying the Doré framework. Charter values cannot be used either to invalidate a statutory provision or render it inoperative in the sense available to such decision-makers if a legislative provision is impugned under the Charter per se. Only the application of the Charter itself can trigger such a remedy, and in such circumstances, additional procedural steps (e.g. issuing a notice of constitutional question) and substantive steps (e.g. the application of the Oakes test) are triggered. Thus, the first logical step in the application of Charter values is to identify the nature and scope of the discretion at issue.

While it is beyond the scope of this paper to elaborate on what constitutes a "discretion," suffice it to say that it may only arise where the wording or context of legislation makes clear its application depends on the judgment of the person authorized to apply it, and where there is more than one possible option available to that authorized person. ${ }^{115}$

\section{2) Identification of potential Charter value;}

Second, the administrative decision-maker must conclude that the identified discretion engages a recognized Charter value (or, potentially, a novel value analogous to an existing Charter value). Administrative decision-makers cannot be expected to be intuitively aware of the range of Charter values; rather, tribunals should develop training and, ideally, guidelines, which highlight the Charter values most relevant to the subject matter of the tribunal. ${ }^{116}$ For example, equality

\footnotetext{
${ }^{114}$ Bell Expressvu Limited Partnership v Rex, 2002 SCC 42 $<$ http://www.canlii.org/en/ca/scc/doc/2002/2002scc42/2002scc42.html>

${ }^{115}$ For discussion, see L. Sossin and L. Pottie, "Demystifying the Boundaries of Public Law: Policy, Discretion and Social Welfare" (2005) 38 U.B.C. Law Rev. 147-87.

${ }^{116}$ The importance of training and enhancing tribunals capacities in relation to Charter application has been highlighted by Sheila Wildeman in her presentations, including the Canadian Institute for the Administration of
} 
and expressive freedom might play a significant role in an education tribunal while privacy, autonomy and fairness might play a more significant role in a social benefits tribunal.

While administrative decision-makers should be open to and consider submissions from the parties on Charter values, it is important to emphasize that fulfilling the goals of Charter values may require "active adjudication" on the part of decision-makers. Active adjudication in this context may involve a decision-maker raising a Charter value on her own (even if not raised by the parties).

\section{3) Balancing from Doré of the value against the statutory objectives as set out in Doré;}

Third, as set out by the Supreme Court in Doré, the next stage of the methodology would be the balancing exercise where the value of the Charter value is weighed against the objectives of the discretionary authority:

How then does an administrative decision-maker apply Charter values in the exercise of statutory discretion? He or she balances the Charter values with the statutory objectives. In effecting this balancing, the decision-maker should first consider the statutory objectives. In Lake, for instance, the importance of Canada's international obligations, its relationships with foreign governments, and the investigation, prosecution and suppression of international crime justified the prima facie infringement of mobility rights under s. 6(1) (para. 27). In Pinet, the twin goals of public safety and fair treatment grounded the assessment of whether an infringement of an individual's liberty interest was justified (para. 19).

Then the decision-maker should ask how the Charter value at issue will best be protected in view of the statutory objectives. This is at the core of the proportionality exercise, and requires the decision-maker to balance the severity of the interference of the Charter protection with the statutory objectives. ${ }^{117}$

While the Court has been explicit in stating this is not simply a different venue for the application of the Oakes approach, it is likely that administrative decision-makers will search for an analogous proportionality framework in order to provide some degree of transparency and rigour in this balancing process. Tellingly, the early applications of Doré, have not yielded innovative templates for this balancing.

One balancing template consistent with Abella J.'s invocation of enriching the administrative law approach would be to adapt the framework developed by the Supreme Court in Baker (and applied to Charter settings in Suresh) in order to determine the degree of fairness appropriate to particular settings. In other words, when considering how to reconcile statutory objectives with

Justice (CIAJ) Roundtable on Administrative Law held in Toronto on May 24, 2013, and forthcoming research on Charter values. See correspondence from Professor Wildeman, June 20, 2013, on file with authors.

${ }^{117}$ Doré, supra at para. 55-56. 
Charter values, the administrative decision-maker should look to the nature and purpose of the statute, the nature of the discretion at issue, the importance of the decision to affected parties, the legitimate expectations of those affected and any specialized procedures - such as applicable guidelines - which may guide the decision-maker. While the proportionality exercise in fairness determinations is of a different kind than that contemplated in Doré, the contextual nature of such determinations seems well suited to working through how Charter values should inform constrains on the exercise of discretion. Under this approach, where a Charter value might undermine the very purpose of a statutory grant of discretion, or it could undermine the nature of the discretion itself, it might be given less weight. Alternatively, where the Charter values amplify the statutory objectives, or where such values are of particular importance for affected vulnerable parties, those Charter values might be given more weight. I would suggest this framework captures the approach Justice Abella adopted in Doré. She acknowledged the importance of expressive freedom and the scope for a lawyer to criticize a judge. She then considered the nature of the statute in question and the importance of the Code in promoting public confidence in the administration of justice and civility among lawyers. Further, she considered the nature of the disciplinary committee's discretion, which is expansive. She noted the impact on Dore himself, highlighting that only a reprimand was at stake. Finally, she acknowledged the committee's deliberative process in determining that Doré's conduct "overstepped" generally accepted norms of "moderation and dignity". 118

We would suggest that such an approach has the added advantage of being familiar and accepted as a legitimate framework among administrative decision-makers, judges and administrative law advocates alike, and where a rich and textured body of jurisprudence and commentary already exists on which to build.

Whatever approach is adopted by a decision-maker, it will be a challenge for parties and advocates to predict at the outset how Charter values might affect their positions in an administrative adjudication. As with the development of procedural fairness within administrative justice, clarity will follow experience, as different administrative decision-makers sort out the proper application of the Doré framework in their statutory context. The courts will have a role to play here as well, both to establish some key parameters and through appropriate deference, to recognize and validate the necessary space for administrative decision-makers to develop an approach to the Charter commensurate with their perspective, expertise and experience.

The proper balancing of Charter values and the objectives of the statute will also depend on the adoption by administrative decision-makers of "active adjudication" strategies. In this sense, while decision-makers may benefit from the submission of parties, they cannot depend solely on such submissions in settings where most parties are unrepresented and cannot be expected on their own to identify and argue Charter values. Further, the importance of active adjudication to the effectiveness of the Doré framework once again demonstrates the importance of tribunal training and resources such as guidelines on tribunal-specific Charter values.

\section{4) Explanation of process and results of balancing in clear reasons;}

\footnotetext{
118 Ibid. at para. 70.
} 
Having engaged in the balancing exercise outlined above, the fourth stage of the Charter values methodology involves setting out a clear explanation for the conclusion reached above. The importance of reasons in this context cannot be overstated. Because of the inherently subjective aspect of the balancing exercise envisioned in Doré, reasons play a dual role. First, reasons will contribute to the credibility and legitimacy of the development of Charter values rooted in the realities of administrative justice. Second, reasons perform an accountability function, confirming both the soundness of the rationale underlying a decision-maker's decision, and assuring a greater degree of consistency and oversight.

We believe the methodology set out above can be adapted to the diverse range of administrative decision-making contexts. Over time, if followed, this methodology would generate a body of training materials, guidelines and reasons on Charter values which, if paired with thoughtful and considered judicial commentary on judicial reviews of such decisions, could result in a constructive and principled framework for the application of discretionary authority in the era of the Charter.

While it is beyond the scope of this paper to explore in detail the deference contemplated by the Supreme Court in Doré applicable to decisions by administrative adjudicators as to Charter values, it follows that the rationale for such deference is the distinctive and different lens on the Charter's application to administrative justice that such adjudicators use. ${ }^{119}$ It is important, through reasons, to see how this lens will come to view the Charter in distinctive terms. Moreover, the standard of reasonableness to be applied to such determinations will depend on reasons in order to ensure meaningful oversight of administrative decision-makers by the Courts.

\section{Conclusion}

In this exploratory analysis, we have sought to advance the view of a sphere of Charter justice that is distinctly suited to administrative justice. We have discussed the ways in which the Charter and administrative law doctrines have been reconciled in the jurisprudence leading up to Doré. We have canvassed the sources of Charter values, and offered a tentative summary of the scope of Charter values to this point in time. Finally, we have discussed how a framework of Charter values could be operationalized with the diverse contexts of administrative justice.

In a sense, the Doré framework opens up the possibility of a new and different kind of Charter dialogue, between administrative decision-makers and courts, in which expertise in policyspecific decision-making contexts may inform the development of Charter values and vice versa.

Our focus has been both on the conceptual coherence of Charter values and on how the Charter can be adapted to the distinct realities of administrative justice. In developing an approach to the Charter rooted not in courts and the formal determination of rights, but in the realm of discretionary decision-making and the oversight of such decisions, we believe the promise of the Charter to protect those affected by the exercise of public authority can at last be meaningfully fulfilled.

${ }^{119}$ Ibid. at para. 36 and 48. 